\title{
Development of the National Agricultural Research System (NARS) in Sri Lanka with special reference to food crops sub-sector : issues related to science policy
}

\author{
Seetha I. Wickremasinghe \\ Science and Tecbnology Policy Research Division, National Science Foundation, 47/5, Maitland Place, Colombo-07.
}

\begin{abstract}
This paper presents a review of the historical growth and development of the National Agricultural Research System (NARS) in Sri Lanka that comprises the agricultural research system, the agricultural education system and the agricultural extension system. It traces the agricultural situation in the country from the early nineteenth century when Sri Lanka (then Ceylon) was under the British rulers and until the present time. It analyzes the British policies adopted towards the agriculture during the colonial period and also discusses the interests of the consecutive governments that came to power after the independence. While mainly concentrating on the development of the agricultural research system with special reference to the food crops sub-sector, the issues related to the agricultural education system and the agricultural extension system are also briefly discussed. The paper gives a comprehensive picture on the contemporary NARS in the country and highlights various agricultural research policies formulated and adopted at different times, which fall within the national science policy framework. Finally, it points out some weaknesses in the present system and indicates a few suggestions as to how such weaknesses should be addressed without delay, to achieve a successful agricultural development in Sri Lanka.
\end{abstract}

Keywords: Agriculture, agricultural research, national agricultural research system, science and technology, science policy, Sri Lanka

\section{INTRODUCTION}

The agricultural sector of the progressively developing countries in Asia (e.g. India) has been remarkably successful in overcoming the constraints on agricultural production through a transition from a growth based on the resource exploitation model, to a growth based on the higher payoff input model. This transition has been possible by a remarkable institutional innovation, and development of the public sector agricultural systems. ${ }^{1}$ The agricultural growth in any country has to be generated via the national agricultural research system. This factor unfortunately remains outside the concern of many politicians and policy makers. ${ }^{2}$ In this context, an examination of the historical growth and development of the agricultural research system (NARS) in Sri Lanka, its contemporary position and the related science policy issues assume significance.

1. Development of the agricultural research system

Sri Lanka was known to the West because of her spices, which attracted the Portuguese to the island. Her maritime provinces came under their domination from 1505 to 1640 . The Dutch replaced the Portuguese and ruled the island from 1640 to 1796 . In the late $18^{\text {th }}$ century, the British made a treaty of alliance with the Kandyan Kingdom of Sri Lanka and captured the Maritime Provinces. Finally, on the 02 March 1815, the entire island came under British administration after signing of the Kandyan Convention in Kandy, the last capital city of the Kingdom of Sri Lanka. ${ }^{3}$

According to De Silva, "although Sri Lanka (then Ceylon) had been under colonial domination (Portuguese, Dutch and the British) for nearly 450 years, it was only during the British rule that a significant endogenous basal structure for science began to appear. Possibly the earliest event of scientific importance in Ceylon (later known as Sri Lanka) was the establishment of the Royal Botanic Gardens at Peradeniya in 1822, which concentrated on the selection, introduction and acclimatization of indigenous and exotic species of flora". ${ }^{4}$

During the early British period, Sri Lanka was not considered as an economically useful acquisition until the commercially viable plantation sector was established in the 1830s. It was first coffee, rubber, coconut, and later when the coffee plantations were destroyed by a fungal disease in 1860 s, tea took its place. 
The progressively increasing stress on an export-oriented plantation sector, naturally led to the decline of the traditional rural agriculture for food and subsidiary crops. This is clearly seen in the reports and papers published in the Tropical Agriculturist during the latter part of the $19^{\text {th }}$ century. ${ }^{4}$ Incidentally, the 'Tropical Agriculturist' founded in June 1881 is said to be the oldest agricultural journal in the East, and certainly it happens to be the oldest journal in the world devoted to tropical agriculture. "Its earlier volumes traced the progress and setbacks in agricultural development in Ceylon, and later began to record the scientific work of the Royal Botanic Gardens, the Ceylon Agricultural Society (founded in 1905) and the Department of Agriculture (DOA), which was established in 1912". ${ }^{4}$

Previously, the establishment of the Colombo Museum in 1876 with separate sections on biology and entomology followed by a section on geology, mineral science and petrological science in 1877 also set the stage for a new scientific orientation in Sri Lanka. ${ }^{6}$

"In 1880, with the appointment of Henry Trimen as Director of the Royal Botanic Gardens, work of high scientific merit was carried out. His treatise of the "Flora of Ceylon", the first volume of which appeared in 1893, remains a masterpiece in taxonomic botany in Sri Lanka". In 1896, after T.C. Willis succeeded Trimen as Director of the Royal Botanic Gardens, some of the pioneering experiments on rubber tapping were carried out.' A scientific journal called Annals of Royal Botanic Gardens was published in 1901.8 In 1902, Willis established the experimental station at Peradeniya, which is said to be a landmark in agricultural research in Sri Lanka. ${ }^{9}$ Willis took the initiative to establish the Dry Zone Research Station at Maha Illuppallama in 1903.10 These were the first attempts to institutionlize agricultural research in Sri Lanka, although still without clear policy guidelines or research orientation.

The formation of the Ceylon Agricultural Society in 1905 was considered as an important event in the historical development of agricultural research ${ }^{11}$, because it was destined to be the nucleus of the future Department of Agriculture. The first task of the Ceylon Agricultural Society was to take over the publication of the journal 'Tropical Agriculturist' under the editorship of Dr. Willis and transform it into a truly scientific journal. It contained papers written by staff of the Peradeniya Experimental Station, local agriculturists and others, in addition to the reprints from most of the principal tropical journals. ${ }^{11}$ With the creation of the Department of Agriculture ${ }^{12}$, more attention was given to arable agriculture. ${ }^{13}$ It is recorded that between 1901 and 1912, Willis had also assembled a team of scientists comprising of a mycologist (T.Petch), an agricultural chemist (M.K.Bamber), an entomologist (E.E.Green), a horticulturist (H.F. Macmillan), an animal husbandry specialist (G.W.Sturgess), a rubber and cocoa specialist (H.Wright) and a coconut specialist (N.K.Jardine) whose scientific contributions were considered to be of the highest caliber by any standard. ${ }^{4}$

"By this time, the country's reputation in the world of tropical agriculture was such that a strong lobby began for the establishment of an Imperial College of Tropical Agriculture, a proposal that later materialized in Trinidad" (quoted from De Silva). ${ }^{4}$ At the time of Willis's retirement in 1912, separate divisions for botany, mycology, entomology, agricultural chemistry etc., were established under the Department of Agriculture. Thus for the first time, research; extension and other scientific services in the field of agriculture came under one administrative authority, although a few enthusiastic individuals like the Gate Mudliyar A.E.Rajapakse were not to be deterred to continue single plot experimentation, independently on private lands. ${ }^{14}$

The period 1900 to 1912 has been described as the 'Golden Age' in the agricultural sciences. ${ }^{5}$ The preliminary attempts to stabilize highland agriculture were started at Maha Illupallama in 1903, with the objective of determining what economic crops could be cultivated under purely rain fed conditions (cotton, tobacco, groundnuts etc.,). Research into the production of rubber began in Sri Lanka in 1909, with the appointment of a chemist, to study the process of coagulation of rubber latex and drying the coagulum. ${ }^{15}$ Studies on coconut were also of significance during the period 1901-1912, as a coconut specialist was recruited for research purposes as mentioned before.

The early activities of the DOA reflected the economic crop bias, mainly related to plant and varietal distribution of species, which on the one hand might be appropriate to peasant cultivation such as cotton, yet operating within the framework of a colonial plantation economy. Indeed the economic crop bias was a persistent theme of the DOA activities until the early 1940s, consistent with an administrative policy of cheap importation of basic food requirements; both rice and wheat, to supplement the short fall in domestic production. ${ }^{16}$

During the first decade of the $20^{\text {th }}$ century, two other important events occurred. The first was the inauguration of the De Soysa Bacteriological Institute 
on the $31^{\text {st }}$ of January $1900 .{ }^{17}$ The second important event was the establishment of the Department of Mineral Survey in 1903.

"Another significant development during this time was the initiative taken by the British authorities to set up research institutes for the plantation sector. These were, of course, mainly to serve the British economic and trade interests, since the research policies of these institutes were very much influenced by what were later recognized as the "Scientific Advisory Committees" for tea and rubber, based in London". "The first such institute to be established was the Rubber Research Institute (RRI), which came into existence at Agalawatte in 1910. This was followed by the Tea Research Institute (TRI) at Talawakele in 1918 and the Coconut Research Scheme (CRS) was established at Lunuwila in 1928 $8^{18-20}$ (Ceylon Administrative Reports-1910, 1918 \& 1928/National Archives), which was later re-constituted as the Coconut Research Institute (CRI). In the case of the TRI and RRI, the Directors and the Divisional Heads were British nationals, while at CRI, the Director was an expatriate. The Director and Head of the Chemistry Division of CRI continued to be in the hands of British nationals until around 1957. It was the intention of the then Board of Management to continue this practice, until the Government stepped in to block this move by the Tea, Rubber and Coconut Research Amendment Act No. 8 of 1957.

With reference to previous studies, ${ }^{21-22}$ De Silva mentions, "yet it is noteworthy that in the early 1930s, these research institutes were instrumental in commencing probably the first ever long term statistically designed field experiments of their kind anywhere in the world. The classical experiment on coconut laid out by M. Salgado in 1935 stood for 30 years while the corresponding experiment on tea, which was started by T. Eden a few years earlier, remained even for a longer period". ${ }^{4}$

While the Second World War did much to focus attention on the importance of domestic food production, it would be untrue to say that this area had been entirely neglected. However, Sri Lankan scientists turned their attention to rice cultivation concentrating mainly on breeding trials for the selection of high yielding pure lines ${ }^{16}$ around 1960 s, long after the Second World War.

"By this time, despite the trauma of a colonial administration, and a British dominated framework for research, an alien scientific culture had become firmly naturalized in the country, although still without being fully indigenized. It was against this backdrop, that the formation of the first Sri Lankan (then Ceylonese) - dominated scientific body (Chemical Society of Ceylon) in the country became significant". ${ }^{4}$

Since then, the number of local scientists including agricultural scientists grew considerably and a local scientific community began to emerge in Sri Lanka by the early 1940s. ${ }^{23}$ Quoting previous studies, ${ }^{24}$ De Silva states that "in December 1943, on a suggestion made by D.H.Wadia, a former President of the Indian Science Congress, the Chemical Society of Ceylon spearheaded the formation of the Ceylon Association of Science ${ }^{23}$, which in July 1944, was constituted as the Ceylon Association for the Advancement of Science (CAAS). The ability of this association to bring together scientists, agriculturists, engineers, medical personnel and social scientists under one banner was indeed a remarkable achievement". ${ }^{4}$

There is a widespread view that one of the many legacies of British colonialism was the absence of trained and qualified nationals. ${ }^{25}$ The evidence from Sri Lanka also supports this fact since from 1942 to 1972 only 12 science students are recorded to have obtained postgraduate degrees locally, compared to 102 in the field of social sciences. Perhaps, it may be due to this reason, that the environment that prevailed during the era just after the independence was not very congenial for building a viable local scientific community. The research institutes were dominated by the British Scientists and the local scientific and technical staff were given only minor roles in scientific activities. ${ }^{26}$ However, the existence of a few qualified Sri Lankan scientific personnel and their dedicated work had been one of the strengths of agricultural research in Sri Lanka during this period.

It must be noted that the work of Joachim, an eminent agricultural chemist, on soils in 1940s was to produce the first soil classification for Sri Lanka, based mainly on edaphic factors, identifying several of the major soil groups and their rough distribution. ${ }^{16}$ Under the influence of E.Abeyratne, during the 1950s and subsequently by C.R.Panabokke, the agro-ecological concept was developed. The credit goes to Panabokke and his team for their soil and soil survey work initiated at Maha Illuppallama. The development of the fertilizer recommendations and trials, studies on rainfall probability and the agro-ecological map whereby twenty two distinct regions were identified by their unique soil and rainfall relationships ${ }^{16}$ are 
some of the significant contributions made during 1960 s to 1970 s that are worth mentioning.

When Sri Lanka gained independence in February 1948, agricultural policies of the government placed a greater reliance on domestic agricultural production, to assist the small farmer to increase production of essential food commodities and to reduce imports. The late D.S.Senanayake, as the Minister of Agriculture and subsequently as the first Prime Minister of Independent Sri Lanka, initiated several farsighted measures towards achieving these goals. Several activities and training programmes were defined by the government within the framework of the implementation of such programmes.

In 1950, the research infrastructure of the DOA began to expand. The Dry Zone Research Station, which was established at Maha-Illuppallama in 1903 was closed down during the war-time and reopened in 1951. The Central Rice Breeding Station, which was established in 1967 at Batalagoda was renamed as the Rice Research and Development Institute (RR\&DI) in 1994. Both were upgraded from former small research structures. Soon after, under the conceptualization of Regional Agricultural Research Centers (RARC) based on agroecological criteria, eight major research centers were established in various parts of Sri Lanka. The Central Agricultural Research Institute (CARI) established in 1967 at Gannoruwa served the entire country. This was the largest multi-crop research organization in the country and its main laboratory complex was built with a generous grant given by the Australian Government. ${ }^{27}$

Post-independence development within the DOA reflects to a certain extent the interests and aspirations of the Government's concern with the problems of domestic production, predominantly of rice. Government policy of increased rice production through strategies of investment in irrigation, dry zone settlement, guaranteed prices, credit and subsidized fertilizer with a certain degree of structural reforms evolved over the time has been a consistent theme of agricultural policy, which dates back to 1930s. The important architectural contribution of Mahinda Silva over this period should be fully recognized, first in his capacity as Director of Agriculture (1963-65) and later as the principal author of the draft agricultural plan 1971-1977 and as Secretary to the Ministry of Agriculture from 1970-1976. ${ }^{16}$

The most significant development during this period was the rice breeding programmes under a set of conditions, that included import restrictions on key food commodities and the consequent import substitution, guaranteed prices for local agricultural produce, credit schemes, subsidies, etc.

The rice breeders during this period realized the inadequacy of the so-called "Old Improved Varieties" (OIV). The first local dwarf variety $\mathrm{H} 4$ spearheaded the increase of the previously stagnant average yield of 1.5 MT per ha to 2.5 MT per ha. While it is true that the efforts of the then Director of Agriculture, Mahinda Silva in relation to agricultural progress was commendable, the development of the so-called "Coordinated Rice Varietal Trials" (CRVT) under the direction of the late Dr G.W.L Peiris, DDR of DOA, and the lead role taken by the rice breeders at Batalagoda led by the late Hector Weeraratne cannot be under valued. The British student Adam Pain, who was doing a study in the late 1970's on Sri Lanka's unique rice breeding programme of the early years, passionately dramatizes the manner in which these rice breeders resisted the internationally driven political pressures to replace existing rice varieties with the so-called dwarf "Miracle Rice" IR-8, produced in Philippines by the International Rice Research Institute (IRRI). The stand taken by local breeders was later proved to be correct when the better adaptable, intermediate stature BG-11 was produced in 1970 that fared much better than IR-8. But the most significant feature of these events was the combined influence of economic policies, as well as the research and science policies of 1960s and 1970s that led to the first "Green Revolution" in Sri Lanka, well ahead of other Asian countries including India, by the late 1970s (although in later years the country miserably failed to exploit and sustain this head-start given during the 1970s). This can be recorded as the major technical achievement in Sri Lanka. Incidentally, the BG Series, popularly known as the "New Improved Varieties" (NIV), helped to increase the experimental station yields to 7MT per ha by 1973. Later with the arrival of a further series of $B G$ varieties, the optimistic prediction of Weeraratne in achieving the record experimental station yield potential of $10 \mathrm{MT}$ per ha, was well within sight by 1980 .

In the mid 1970s, beverage and spice crops plus livestock and veterinary science, which were under the overall research arm of the DOA were reallocated in new Ministries responsible for these commodity groupings. As a result the Department of Minor Export Crops was established in 1973. The Veterinary Research Institute (VRI) took over the broader functions of R\&D on livestock under the direction of a new department established for Animal Production and Health (DAPH). 
The Agrarian Research and Training Institute was established in 1972 and subsequently renamed in 1984 as the Hector Kobbekaduwa Agricultural Research and Training Institute (HKARTI), which was expected to undertake research on agrarian research issues of Sri Lanka as well as of the Asian region. The fishery subsector remained marginalized in $R \& D$ until the National Aquatic Research Agency (NARA) was established in 1981. Among plantation research institutes, the Sugarcane Research Institute (SRI) was the last to be established at Udawalawa in 1984.

As recommended by an S\&'T policy report published in 1986 (discussed towards the end of the paper), the Council for Agricultural Research Policy (CARP) was established in 1987. As for other reorganization programmes proposed for the DOA, no action was taken until much later. On the $01^{\text {st }}$ of January 1994, the DOA, which for 90 years or so had been regimented to operate a centralized administration, was decentralized and regionalized based on the commodities. However, it must be mentioned that the important Science Policy implication of this dismantling process was the shift from discipline based scientific investigations to commodity-based research. A key objective of this move was to ensure the realization of an end product in research. Due to the above policy decision, the new R\&D Centres that evolved in 1994, replacing the CARI, were the Plant Genetic Resource Centre
(PGRC), Horticultural Research and Development Institute (HORDI), and the Plant Quarantine Centre (PQC) etc. ${ }^{28}$

Since the fascinating events that followed in the food crops sub sector are discussed in the reports available at CARP, this review will not elaborate on such issues. These reports include the following World Bank and GTZ sponsored studies:

i. Resource utilization in the Sri Lanka Agricultural Research System: Pbysical Resources in the Department of Agriculture and the Department of Export Agriculture by M.A.T. De Silva. Sri Lanka Council for Agricultural Research Policy, Colombo- June 1995.

ii. The External Review of the Department of Agriculture by R.S.Jayaratne, Y.D.A.Senanayake, S. Jogaratnam \& late S. Kathirgamathaiyah \& M.A.T. De Silva. Sri Lanka Council for Agricultural Research Policy, ColomboNovember 1999.

By 2000, the NARS in Sri Lanka consisted of 14 main institutions based in six government ministries. ${ }^{28}$ However, with the formation of a new government in November 2005, the contemporary agricultural research system in Sri Lanka came to consist of 16 main organizations or institutions coming under five (05) different ministries as indicated (Table 1).

Table 1: Contemporary National Agricultural Research System (NARS) in Sri Lanka*

\begin{tabular}{ll}
\hline Ministry & \multicolumn{1}{c}{ R\&D Organization } \\
1. Agricultural Development & Council for Agricultural Research Policy (CARP) \\
& Department of Agriculture (DOA) \\
& Department of Animal Production \& Health (DAPH) \\
& Department of Export Agriculture (DEA) \\
& Hector Kobbekaduwa Agrarian Research \& Training Institute (HKARTI) \\
& Post Harvest Technology Institute (PHTI) \\
& Coconut Research Institute (CRI) \\
& Rubber Research Institute (RRI) \\
& Tea Research Institute (TRI) \\
& Sugarcane Research Institute (SRI) \\
& Cashew Corporation \\
& National Aquatic Resources, Research \& Development Agency (NARA) \\
3. Fational Aquaculture Development Authority (NAQDA) & Forest Department \\
Fisheries \& Aquatic Resources & Postgraduate Institute of Agriculture (PGIA) \\
5. Education & Faculties of Agriculture (08) \\
\hline
\end{tabular}

* modified from Senanayake (2000) 
There are eight other organizations or institutes that support agricultural research in the country either directly or indirectly. These are as follows.
a). Industrial Technology Institute (ITI)
b). Irrigation Department (ID)
c). National Science Foundation (NSF)
d). Central Bank/Economic Research Division -
e). Department of Census \& Statistics
f). Department of Meteorology
g). Bandaranaike Memorial Ayrveda Research Institute (BMARI)
h). Institute of Fundamental Studies

The external review system for research institutions introduced by CARP in 1993 has provided useful information on the infrastructure, resources, research outputs, constraints, linkages and management in the NARS. The National Agricultural Research Plan (1999) prepared by CARP has laid foundations to prepare realistic research agendas in agriculture for the next five years. ${ }^{28}$ The interest of the GOSL, however, seems to concentrate on the Ministry of Agriculture and Livestock publishing a new policy document in January 2003, namely the National Policy on Agriculture and Livestock for the period 2003-2010. The National Agricultural Research Policy document of April 2003, published for the first time by CARP, is another landmark for the development of agricultural research in the country.

\section{Development of the agricultural education system}

In Sri Lanka, agricultural education is nearly hundred years old and had received attention at the school garden level. The first training course for teachers commenced in Peradeniya, the Kandy district in 1916. Two Farm Schools were also set up for school leavers who wished to follow a diploma course in agriculture. Since then, several more practical Farm Schools were established in different parts of the country to train farmers. ${ }^{29}$

The higher education system in agriculture commenced in 1948 with the establishment of the former Faculty of Agriculture and Veterinary Science, in the University of Ceylon, Peradeniya Campus. For many years it's principal function was the training of undergraduates to serve the agriculture and livestock sub-sectors. Then an increase in enrolments began to take place from the 1960's. The University of Ceylon had its academic structures and traditions derived from the British University model in which postgraduate training was offered principally in faculties as an
- Ministry of Science \& Technology

- Ministry of Irrigation

- Ministry of Science \& Technology

$$
\text { Ministry of Finance \& Planning }
$$

- President's Secretariat

- Ministry of Disaster Management \& Human Rights

- Ministry of Indigenous Medicine

\section{- President's Secretariat}

extension of the development of undergraduate programmes. During a 27-year period (1948-1975), although 25 postgraduate students were registered, only five degrees had been awarded. ${ }^{30}$ The Board of Governors of the University of Ceylon appointed an Expert Committee in July 1972 to examine the higher level manpower requirements to accelerate the developments in agriculture, which recommended the institutional arrangements required to develop postgraduate education in agriculture. In 1972, when the University System was reorganized, and for good reasons, the Faculty of Agriculture and Veterinary Sciences was separated, and renamed as the Faculty of Agriculture and the Faculty of Veterinary Medicine and Animal Science respectively. After gaining independence status, the Faculty of Agriculture grew fast and the number of student enrolments increased rapidly. ${ }^{28,31}$ However, the Faculties of Agriculture were formally recognized as part of the NARS only recently, with the formulation of National Agricultural Research Policy 2003-2010 by CARP.

During this period, the first degree in agriculture, which was of three years duration earlier, was transformed into a four-year course. The Expert Committee's deliberations also led to the establishment of the Post-Graduate Institute of Agriculture (PGIA) in June 1975. The decision to create an independent Institute for furthering postgraduate education in agriculture was of tremendous significance. It provided the institutional structure for diversified changes in the sphere of training and management of higher education in agriculture. The late Professor R.R.Appadurai was the first Director of the Institute. Over the years, the number of universities as well as the number of Faculties of Agriculture increased and now there are eight of them under the University System as indicated below (Table 2). 
The number of staff of the Faculty of Agriculture at the University of Peradeniya (UOP), which was 30 in 1974 , increased to 83 in 1992, with 47 of them having post graduate degrees at the PhD level by $2000 .{ }^{32}$ By the end of 2003 the number of the total staff in the Faculty of Agriculture of the UOP was 102, out of which 81 had post graduate qualifications at the $\mathrm{PhD}$ level. The total staff of the agriculture faculties of all the universities in 2004 was $247 .^{33}$

From 1980, undergraduate training in agricultural science began to expand with the establishment of new ties with the other agriculture sector institutes. Also, many Faculties of Science in the universities contribute to human resource development (HRD) in the sector of agricultural S\&T. During the last 25 years the research capabilities of the higher education system began to increase. This was due to the larger pool of trained academic staff and the increase of postgraduate students, primarily due to the establishment of the Post Graduate Institute of Agriculture (PGIA) in 1975, which arose as a result of the government recognizing the need for highlevel manpower for the development of the agricultural sector. This resource base, in the form of infrastructure, manpower and finances, has continued to expand to address S\&'T issues. It is expected that this base will continue to grow. ${ }^{28}$ From the period 2000-2003 academic years, the output of postgraduates from the PGIA ( $\mathrm{PhD}$ 07; Mphil-35; MSc-204) was $246^{33}$, which is a significant contribution to HRD in agriculture.

At present, there are no State Agricultural Universities in Sri Lanka as in the case of India. Whether any such institution is necessary is a debatable issue. It has to be recognized however, that, Sri Lanka being a very small country compared to India, can ill offer to spread thinly its limited resources for such institutions, especially when there are agriculture faculties already established in different regions in the country.

\section{Development of the agricultural extension system}

The agricultural extension system that has a development role began to grow from 1920 when the DOA began to stabilize following its creation a decade earlier. Growth of the extension arm became most visible after the 1960 s when the DOA began to consolidate, redefine and refine its extension functions. ${ }^{34}$

The DOA extension system was mission oriented in the transfer of technologies as it had strong linkages with the research arm and was functioning well until early 1980s. ${ }^{28}$ Then with the Constitutional Amendments of the Government of Sri Lanka (GOSL) in mid 1980s, agricultural extension was relocated from national responsibility to a provincial function. The provisions of the $18^{\text {th }}$ Amendment to the Constitution provided the basis for decentralisation and regionalisation of agricultural extension. But this was not as simple as it is made out here. There was the provincial extension system under a Provincial Director of Extension, and an inter-provincial extension system operated centrally by the Extension and Communication Division of the DOA. This is similar to the case in India where agricultural extension is a state subject handled through the DOA.

In the non-plantation crops (food crops) sector of the DOA, the extension services went through a series of reforms. Although agricultural extension commenced way back in the 1920s when research farms were established, extension services became institutionalized only in 1963 when, for the first time, a Division of Extension was established in the DOA headed by a

Table 2: Date of establishment of an agriculture faculty in different universities

\begin{tabular}{ll}
\hline Name & Year \\
\hline Faculty of Agriculture and Veterinary Science, University of Ceylon, Peradeniya Campus & $1948^{*}$ \\
Faculty of Agriculture, University of Peradeniya, Peradeniya & 1972 \\
Faculty of Agriculture, University of Ruhuna, Matara & 1978 \\
Faculty of Agriculture, Eastern University, Batticoloa & 1981 \\
Faculty of Agriculture, University of Jaffna, Jaffna & 1990 \\
Faculty of Agriculture, Sabaragamuwa University, Boralanda & 1995 \\
Faculty of Agriculture, Rajarata University, Mihintale & 1995 \\
Faculty of Agriculture, Wayamba University, Makandura & 1999 \\
Faculty of Agriculture, Uva Wellassa University, Badulla & 2005 \\
\hline * Ceased to function after 1972 &
\end{tabular}


Deputy Director (Extension). With these developments, the District Agricultural Officers, Agricultural Instructors and Krushikarma Viyaptha Sevaka (KVS), who were already in the extension service, were re-deployed in the Extension Division.

Since then a number of evolutionary changes took place. Historical evolution in this direction is very well documented in two studies, one of which was financed by the World Bank and the other by GTZ. The reports published by CARP document the critical policy issues involved in the introduction of various extensive mechanisms until the end of the last century, viz.,

i. Technology Transfer in the Non-Plantation Crop Sector: Performance, Problems and Issues by S.P.F. Senaratne et al. Sri Lanka Council for Agricultural Research Policy, Colombo- March 1995.

\section{ii. Towards a better Integration of Research, Extension and Development by M.A.T.De Silva \& D.T.Wettasinghe. Sri Lanka Council for Agricultural Research Policy, Colombo - September 1999.}

Since 1980, the activities of the Extension Division have been organized within the framework of the Training and Visit System (T\&V) of the Adaptive Research and Extension Project funded by the World Bank. The Division is also responsible for pre-service training, in- service training of extension staff as well as institutional vocational training in the country. New rechnologies developed by the Research Division of the $\mathrm{DOA}$ are incorporated into these training programmes.

There is also an established interaction between the Extension and the Research Divisions via Regional Technical Working Groups (RTWG). RTWG have preseason meetings, mainly to organize and prepare farmers to face the challenges of seasonal issues and problems. At these meetings, (held twice a year) the field level problems are highlighted by extension staff and discussed with both the Research and the Extension Divisions. At these meetings consensus is reached as to the priorities for research in a particular region. Additionally, research-extension dialogues as well as field days are organized regularly (personal communications).

In the plantation crop sector, extension was part of the research process, and was located within the research institutions from the very inception. However, in the coconut plantation sector, the Coconut Cultivation Board was established in 1972 as per the Coconut
Development Act No. 46 of 1971. The extension and advisory functions of the CRI were also transferred to the Coconut Cultivation Board.

It must be noted that in Sri Lanka at present, the agricultural extension system is spread among many institutions located in different national and provincial ministries. For plantation crops, they are in the particular research institutes (TRI, SRI) or in semigovernment organizations such as the Tea Smallholdings Development Authority, Coconut Cultivation Board etc. For other commodities, it is the function of a government department, i.e. Department of Export Agriculture (DEA).

\section{Science policy initiatives relevant to agriculture}

Science policies adopted for Sri Lanka by the British during the colonial era were confined to exploration, surveying, data gathering and application of techniques to promote colonial economic policies which were similar to the policies they adopted in the case of India. The main motivation for restricting the policies to the use of modern Science and Technology (S\&'T) in the colonies was obviously for commercial interest.

In Sri Lanka, it is mainly tea, rubber and coconut plantations that were of interest to the British. They also had interests in pearls in the sea around the country. Their S\&T policies were focused on the development of railway, communication and ports for facilitating transport of the commercially produced finished (i.e. tea) and intermediate products (i.e. crape rubber, desiccated coconut). The policies were also extended to establish medical research for the betterment of the British and other European people who were engaged in civil administration, military, surveys and exploration studies. Research on animal science was also promoted since cavalry was used in the military.

It is clear that the colonial rulers were interested only in the plantation crops and not in the food crops until the time of the major famine that occurred in the late $19^{\text {th }}$ century in India which also affected Sri Lanka. Due to the two World Wars, the British regime was compelled to pay attention to cultivate food crops in the country and it shed light on the development of agricultural research using the S\&T approach. Also their S\&T policies regarding HRD were such that the locals were not given a chance to serve in the responsible positions in the science and research stream. Such policies continued even after Sri Lanka 
gained Independence, because of the exclusive dominance of a small western educated class of Sri Lankan elitists.

Many scientists in Sri Lanka agree that it was during the British regime that the country was able to develop the infrastructure facilities and training relevant to scientific pursuits. However, many also believe that had the local scientists been allowed to serve in the responsible scientific positions and given research responsibilities at the decision making level in the agriculture sector, the country would have progressed much more by now (personal communications).

The government of independent Sri Lanka has paid much attention to agriculture, and considered it as a top priority sector. Deviating from the policies of the British, the consecutive governments that came to power have strengthened the policies in S\&T towards food crops. The political leaders and the leading scientific community in the country were keen on formulating national development plans incorporating science policies that focused on the development of agriculture as a key issue. However, despite these attempts, it is evident that the progress made in agricultural development in Sri Lanka is low.

Unlike the Indian situation, Sri Lanka has been lagging behind in working out a sound economic plan for the development of the country including agricultural research since she gained independence in 1948, perhaps due to lack of strong political commitment.

Like India, the agriculture sector is politically important to Sri Lanka, because the bulk of the electorates are rural and dependant on agricultural pursuits. Since independence, all governments, without exception, have placed heavy emphasis on the development of the agricultural sector. Table 3 shows the strategies recommended for improving the agricultural sector by various development plans since independence. ${ }^{35}$

Table 3: Development plans worked out for improving the agriculture sector

\begin{tabular}{|c|c|c|}
\hline & Plan & Strategies \\
\hline i & $\begin{array}{l}\text { The Six Year Prgramme of } \\
\text { Investment } 1954 / 55 \text { to } 1959 / 60\end{array}$ & $\begin{array}{l}\text { Use of surpluses in the export sector } \\
\text { for agricultural development. }\end{array}$ \\
\hline ii & $\begin{array}{l}\text { The Ten Year Plan (1956) } \\
\text { (was given up due to adverse } \\
\text { changes in the economic situation) }\end{array}$ & $\begin{array}{l}\text { Irrigation and land development. } \\
\text { Improvement of agricultural } \\
\text { productivity. Development of } \\
\text { specific crops. Improvement of } \\
\text { animal husbandry. }\end{array}$ \\
\hline iii & $\begin{array}{l}\text { The Short-Term Implementation } \\
\text { Plan (1961) }\end{array}$ & $\begin{array}{l}\text { Greater emphasis on plan strategies } \\
\text { outlined in the Ten Year Plan. Import } \\
\text { substitution on specific food items. }\end{array}$ \\
\hline iv & $\begin{array}{l}\text { The Agricultural Development } \\
\text { Proposals (1965-1970) }\end{array}$ & $\begin{array}{l}\text { Import substitution (mainly rice). } \\
\text { Diversification through cultivation } \\
\text { of subsidiary food crops. Adoption } \\
\text { of intensive cultivation techniques, } \\
\text { high yeild varities (HYV), fertilizers } \\
\text { etc. Opening of new land. Improvement } \\
\text { of irrigation facilities. Improvement } \\
\text { of animal husbandry. }\end{array}$ \\
\hline $\mathrm{v}$ & $\begin{array}{l}\text { The Five Year Plan } \\
(1971-1975)\end{array}$ & $\begin{array}{l}\text { Opening up new land. Consolidation } \\
\text { of strategies already implemented. } \\
\text { Emphasis on drift irrigation. }\end{array}$ \\
\hline vi & $\begin{array}{l}\text { The Five Year Rolling Plans } \\
(1977-1997)\end{array}$ & $\begin{array}{l}\text { Accelerated Mahaweli Development } \\
\text { Programme (irrigation and power } \\
\text { generation). National agriculture, } \\
\text { food and nutrition strategy. }\end{array}$ \\
\hline vii & $\begin{array}{l}\text { The Six Year Development } \\
\text { Programme (1999-2004) }\end{array}$ & $\begin{array}{l}\text { Development on agricultural } \\
\text { production with special emphasis } \\
\text { on paddy production. }\end{array}$ \\
\hline
\end{tabular}


Reference should also be made to the brief period from January 2002 to April 2004 when the then government proposed and partly implemented a series of reforms through a new state policy document titled "Regaining Sri Lanka" ${ }^{36}$, which highlights greater involvement of the private sector in agricultural Research and Development (R\&D). Although many people had reservations about the reforms proposed in this policy document (personal communications), some of the policy measures were implemented during this period, and this includes the privatization of the country's long established state-owned seed producing farms. Some of the striking policy reforms proposed in "Regaining Sri Lanka" are reproduced below.

a) "Government will give priority to encouraging smallholders to cultivate high value horticulture crops, livestock and fisheries products. Lowincome farm households can increase returns by diversifying production out of low-value crops into higher value agricultural commodities" (Page 63).

b) "In the future, the private sector will play a far greater role in agriculture research and development. With donor support, the private sector will engage in contract research for perennial crops. Management of crop and livestock extension will be progressively contracted out to the private sector. While the government will bear the costs of extension during its first few years of private management, cost recovery systems will need to be instituted to ensure that agriculture extension can become selffinancing." (Page 63).

c) "To ensure that commercial agri-business investors can access world-class agro-technology in a timely manner, the Board of Investment will establish a special facility for facilitating the import and phyto-sanitary clearance of seeds and planting material. In close consultation with the private sector, a new Seed Law as well as draft regulations under the Plant Protection Act of 1999 will be prepared. In accordance with the new Seed Law, Government will confine itself to the production of basic seed." (Page 63).

d) "Greater private sector participation will be encouraged in many aspects of agricultural support services. Government will divest itself of its residual corporate holdings in the dairy, sugar milling, and various agro-input industries. Government will also lease-out or sell a number of its seed farms and livestock farms for private sector operations. Government will also gradually turn over the management of state forestry plantation to the private sector." (Page 64).

e) "All commercial activities, such as production and marketing of fish, fishing boats and gear, fuel, ice plants, and processing facilities, will be within the purview of the private sector, with government providing supporting infrastructure, and an enabling policy setting." (Page 64).

For the first time in agricultural research history, CARP has prepared a National Agricultural Research Policy ${ }^{37}$ for a period of seven years from 2003-2010 clearly identifying priorities and strategic areas of importance. It has placed emphasis on priority setting and strategic planning; human resources management and development; enhanced funding for research; improve effectiveness of NARS; role of private sector; links with regional and international institutions; role of universities; transfer of technologies; regulatory mechanisms; policy research etc.

Agricultural and the related science policy development in Sri Lanka will not be complete, if a reference is not made to the present government policy document, "Mabinda Chinthana" ${ }^{8}$ (Mahinda Vision), which was put forward by His Excellency the President Mahinda Rajapakse during the Presidential Election 2005. The chapter on Agricultural Renaissance identifies issues important for upgrading domestic agriculture, such as scarcity of water, non-availability of land, crop losses, poor markets for agricultural produce and lack of technology. The followings are some important policies relevant to agriculture that will be adopted under the "Mabinda Chinthana".

\section{a) Non-Plantation (Food) Sector}

i. Completion of 10,000 tanks and implementation of multipurpose irrigation scheme.

ii. Formulation of National Land Policy.

iii. Launch of programme to produce seeds in a competitive manner by ensuring the development of state owned seed research farms to make seeds available at cheaper price. This issue is in contrast to policies identified in the "Regaining Sri Lanka" document by the previous government.

iv. Offer $50 \mathrm{~kg}$ bags of all types of fertilizer at Rs.350/- to farmers to increase the agricultural and plantation productivity. 
v. Provision of the required agro-technologies to farmers.

vi. Funds for Agricultural Cooperative Societies to provide equipment and tractors to farmers.

vii. Agricultural Development Act will be amended to extend more benefits to farmers.

\section{b) Plantation Sector}

i. Arrangements to re-invest the proceeds of the "Cess" levied on tea smallholdings and financial facilities and tax concessions for modernization of tea factories.

ii. Development of coconut cultivation beyond the traditional coconut triangle and launch programmes for market for desiccated coconut and coconut oil industry.

iii. Increase of replanting subsidy for rubber (Rs. 106,000 per hectare).

iv. Popularization of sugarcane cultivation among smallholders.

\section{c) Other sectors}

i. Strengthen the local dairy industry by providing incentives to establish small and medium scale factories to produce dairy products.

ii. Upgrade fisheries industry and maximize the use of ocean resources.

Under the Chapter on Science and Technology, the Mabinda Chinthana emphasizes on R\&D and application of science and technology at village level through programmes such as: a) "Vidatha" (Vidya Dana Thakshanaya) Resource Centres, a concept of Hon. Prof. Tissa Vitarana, Minister of Science and Technology, which is now being established by the Ministry of Science and Technology, b) "Nana Sala" Rural Knowledge Centres initiated by the Information and Communication Technology Agency (ICTA), to provide computer technology and internet facilities to villages so as to improve ecommerce transactions. The Govi Sabana Sarana, a toll free information service established recently by the Ministry of Agricultural Development to provide technical advice to farmers to rectify the deficiency of the extension services is another step put forward in this direction.

\section{Development of S\& T policy trends}

Agricultural development and advancement will not be effective in the absence of proper S\&T policy directions because the basis for $\mathrm{R} \& \mathrm{D}$ in agriculture must fall in line with such overall policies. In this context, the development of S\&'T policy trends in Sri Lanka also assumes significance, which is discussed briefly.

The formation of the Ceylon Association for the Advancement of Science, CAAS (renamed later as Sri Lanka Association for the Advancement of Science, SLAAS) in 1944 was indeed the turning point in science policy orientation in Sri Lanka. Within four years of its inauguration, it began its historical agitation to get the politicians and administrators to recognize the role of science and the scientists in national development. ${ }^{4}$ Besides, science education too had a slow beginning with a few locals having the privilege of educating their children in British Colleges mostly on subjects such as theology. ${ }^{39}$

Immiediately after the nation's independence, the scientists of Sri Lanka pressed hard for a national organization for science and technology. The model proposed then was the Indian one, with its historic "Science Policy Resolution" through which the Prime Minister of India automatically became the Minister for Science- a tradition every Prime Minister of India has to this date maintained. ${ }^{40}$ Based on this, scientists of Sri Lanka put forward a proposal for the creation of a national research council, which was presented to several governments since independence. As a consequence of this, the National Science Council (NSC) was created in 1968. Since then, the NSC submitted several policy recommendations to the Governments but they were not considered seriously, may be due to the lack of political appreciation for science planning in the country. The National Science Policy Statement (1969); The Seven Point Science Policy Statement formulated by the Executive President in December 1978, which was officially accepted as the National S\&T Policy; A report on Postgraduate Training of Scientists (1979); A report on Upgrading Science Education in Rural Schools (1979); are some examples. ${ }^{41}$

In June 1982, the NSC Act was replaced and in its place the Natural Resources, Energy \& Science Authority (NARESA) was created. ${ }^{42}$ The NSC and its successor NARESA, which were semi government institutions under the Ministry of Science, Technology and Human Resource Development, played a major role in funding research in all areas of S\&T including agricultural research until the establishment of CARP in 1987. Since then CARP funds agricultural research on a large scale. 
The first comprehensive National Science and Technology Policy for Sri Lanka ${ }^{43}$ was prepared in 1986 by the National Science Policy Coordinating Committee (NSPCC) with the Chairmanship of Professor Cyril Ponnamperuma, on the invitation of His Excellency, the then President, J.R. Jayawardene. But this policy document was not promulgated by the Government. Over 100 scientists were organized into nine sectoral committees viz., a) Agriculture, forestry and fisheries, b) Agriculture research complex, c) Science policy in industry, d) Electronics and computer science, e)Energy, f) Environment, g) Science education, h) Health and nutrition, i) Social infrastructure. These were essentially "state of art" reports that documented the past and on-going sectoral work, but devoid of a policy vision for the future. The final report that was published as the National Science and Technology Policy for Sri Lanka was an integrated concise version of the nine sectoral reports. With a number of foreign consultants also participating in the formulation of this document, this exercise is said to be the most extravagant activity ever undertaken for drafting of a science policy for Sri Lanka. Paradoxically neither SLAAS (Sri Lanka Association for the Advancement of Science) nor NARESA officially participated in this exercise, although NARESA was the then state institution mandated to undertake formulation of science policies. With the rational and unrealistic objectives, goals and targets, especially in respect of agricultural research and development, this science policy document was pigeonholed; never to be seen or heard again (personal communications).

These sectoral reports were detailed studies of the existing climate of science and technology in the country at that period of time. The recommendations made in all sectors emphasized the lack of organization and leadership in the scientific sector and the lack of recognition of the role of scientists in the country's strategies for development. This report outlined the basic science inputs that should go into policy-making and development planning, emphasizing the need to evolve an integrated science based approach to policy planning. It recommended that an apex structure be established for each sector with mandate for the projection of the needs of the sector, for monitoring and coordinating research and development within the sector and for advising the government on issues related to the sector. Examples of such bodies as given in the report were Agricultural Research Council, Medical Research Council, Industrial Research Council, Council for Science Education and Research etc.. It further recommended that directorates of these bodies be constituted to include scientists, planners and decision makers at the Ministry level. ${ }^{44}$
The Council for Agricultural Research Policy (CARP) that was established in 1987 is a good example of an organization established on the recommendation made in the S\&T Policy document published in 1986. CARP owes its creation and existence to the World Bank funded project called "ARP". This document too, however, did not receive the endorsement of a large section of the scientific community in Sri Lanka and also it was never implemented. One of the major criticisms leveled against it was that the recommendations geared towards the establishment of new organizations rather than towards strengthening R\&D capability within those already in existence.

In 1995, when Prof. Priyani E. Soyza was the Director General, NARESA also prepared a "National S\&T Policy and a Plan of Action" 45 and submitted to the then Ministry of Science, Technology and Human Resource Development. In this document, it has been highlighted under agriculture, the need to improve linkages and information flow between the different $\mathrm{R} \& \mathrm{D}$ institutions dealing with various aspects of agricultural research. It has been recommended that these improvements be directed towards organizing joint research programmes which permits co-ordinated research activity (Page 28). There are no records of any official acceptance or follow up action taken on this document to date.

Again in April 1998, the Government took a decision to reconstitute NARESA as the National Science Foundation (NSF) on the recommendations made by the 1991 Presidential Task Force (PTF). This was followed by the Science \& Technology Development Act 1994.

The recommendations of the PTF report in a way reiterated the earlier report of 1986 on the National Science and Technology Policy for Sri Lanka. It dealt with industry, agriculture, unemployment, income distribution and poverty in the context of the country's (then) current development plans and policies. ${ }^{44}$ The PTF Report also recommended several restructuring measures in respect of scientific and $R \& D$ institutions, which were incorporated in the Science and Technology Development Act 1994, which was passed in the parliament and is now in effect.

\section{Concluding remarks}

The above review gives us a broad picture on the evolution, growth and organization of the NARS in Sri Lanka over the years and its contemporary status. Being a former British colony, Sri Lanka has experienced the hardships as well as the development 
strategies adopted by the British rulers with regard to science and technology policies and agricultural research policies. It is noted that there has been a slow growth and development in the agricultural sector since independence to date.

Since independence in 1948, Sri Lanka has also been inefficient in working out a sound economic plan and implementing it for the development of the country. This may be due to lack of strong political commitment and the fact that the funds allocated by the government for $R \& D$ in all fields of sciences including agriculture is very low. As at now it is only about $0.17 \%$ of GDP.

The different plans related to agriculture show that policy makers in Sri Lanka tend to view the agricultural sector as basically comprising two categories; peasant-based domestic agriculture sector and plantation sector consisting of the perennial crops- tea, rubber and coconut. While the plantation sector assumes great importance from the point of view of export earnings, it must be mentioned that the success of an economic plan or political programme in the country depends on the productivity and the progress in the domestic agricultural sector.

There is no integrated and comprehensive policy document for agricultural development, education, research and extension. The reason for this may be the location of agricultural S\&T institutions under many ministries. This has led to the formulation of mary policy and planning documents by the relevant ministries and institutions. In the implementation of recommendations of many reports from different ministries, there is much overlap at national implementation efforts, and there is undue competition for scarce resource. ${ }^{27}$ Due to the same reason, there is a gap between coordination of such issues among the ministries. No single authority takes the responsibility. The consecutive governments that came to power have not considered agriculture as a common national issue. The governments consider agriculture as a major national issue, but there was no common understanding, or a consistent stand on national policy and development. Unlike our neighboring country India, every government formed in Sri Lanka has its own agenda towards agriculture. This has led to problems in implementation of science policies in agriculture.

The last S\&T policy document that attained some degree of integration and comprehensiveness in agriculture had been prepared twenty years ago. ${ }^{46,47}$ However, the national policy framework for Agriculture published by the then Ministry of Agriculture, Land and Forestry in 1995 and the National Agricultural Research Plan of 1999 published by CARP ${ }^{48}$ have laid foundations to prepare a realistic research agenda with visionary targets of the NARS for the next 5-6 years.

It must also be mentioned that due to structural weaknesses and lack of legitimacy and authority, the functions of CARP as an inter-ministerial organization for coordinating agricultural research (functions expected to be similar to Indian Council for Agricultural Research) has not been successful enough. Inadequate funds, inadequate research infrastructure and poor coordination among research institutes, universities and scientists are the major stumbling blocks in Sri Lanka for R\&D in agriculture. Sri Lanka is still experiencing difficulties due to lack of consistent S\&T policies in agriculture. Therefore, inconsistent $S \& T$ policies in agriculture and poor implementation of currently available policy recommendations are the major issues that hinder $R \& D$ in agriculture in the country.

As highlighted by previous studies ${ }^{49}$, CARP may be upgraded by giving legitimacy and authority to function as an inter-ministerial organization to strengthen the effective coordination among the relevant government departments, agricultural research institutes and universities (Faculties of Agriculture), for proper coordination of agricultural research in the system.

On invitation by one of the previous governments, Prof. M. S. Swaminathan, Chairman of the M.S.Swaminathan Research Foundation (MSSRF), Chennai, India visited Sri Lanka and he too had submitted an advisory report. ${ }^{50}$ However, there is no clear indication as to whether the issues raised in his report have been implemented.

The Ministry of Agriculture and Livestock (2003) prepared a new National Policy on Agriculture and Livestock ${ }^{51}$ recognizing the need for efficient and effective resource utilization in line with national and international trends and opportunities for sustainable agriculture. This document too considered rice production as top priority. The two new Ministries (Ministry for Agriculture, Irrigation and Mahaweli Development and Ministry for Agricultural Development) in the present government also have given priority to rice production and domestic 
agriculture. It is planned to mobilize resources for rice self-sufficiency, produce varieties for which foreign demand exists, and to produce a surplus to be utilized in an expanded value added rice based food industry.

As for future trends of $H R D$, it has been planned to train $75 \%$ of Sri Lanka's agricultural research staff in the South Asian region as part of a regional training programme of the CARP. The government has raised the budget of the Competitive Contract Research Grants Programme (CCR GP) up to Sri Lankan rupees 125 million. CCRGP is intended to support demanddriven research to ensure high factor productivity, sustainable domestic food supplies and excess production for export. CARP has also received nearly 15 million Sri Lankan rupees from the Asian Development Bank (ADB) for the Perennial Crop Development Programme to be disbursed in the form of research grants. Though the private sector research contribution is still small, it has been planned to encourage the private sector through collaborative work with government agencies and the universities. Despite the increase of funds for agricultural research, it represents only a very small percentage of the total agricultural R\&D spending. ${ }^{52}$

In conclusion, it may be said that local policy makers and political leaders have always agreed that, from a political and social point of view, it is imperative to establish a domestic agricultural system that offers the peasant farmer a good standard of living, which in turn contributes to the socio - economic development of the country. However, it is obvious that finding a mechanism for the effective implementation of such policies has not so far been very successful. Therefore, it is of utmost importance to address the issue of implementation of sound policies without delay, if a successful agricultural development is to be achieved in the country.

\section{Acknowledgement}

The author appreciates the critical and constructive comments made by the referees, which helped in improving this review substantially. Since part of this work was carried out as research towards the $\mathrm{PhD}$ programme of the author, close guidance of the two supervisors, Prof. V.V.Krishna, Chairman, Centre for Studies in Science Policy, Jawaharlal Nehru University, New Delhi and Dr Mruthyunjaya, Former Director, National Centre for Agricultural Economics and Policy Research, New Delhi is gratefully acknowledged. The author is also thankful to the Swedish International Development Agency for sponsoring the study programme.

\section{References}

1. Ruttan V.W. (2001). Technical change in agricultural development. In: Technology, Growth and Development, pp. 207-210, Oxford University Press, USA.

2. Mellor J.W. (1996). Accelerating agricultural growth: is irrigation institutional reform necessary? The Pakistan Development Review 35:399-417.

3. Narional Archives (1815). Kandyan Convention, Search Room Copy, lot 21/35, National Archives, Reid Avenue, Colombo.

4. De Silva M.A.T. (1984). Historical landmarks in the orientation of science planning in Sri Lanka. Sri Lanka Journal of Social Sciences 7 (182): 77-96.

5. Schokman D. (1981). Tropical Agriculturist: 1881-1981. Tropical Agriculturist 137:11-12.

6. Wijesinghe L.C.A.De S. \& De Silva M.A.T. (1981). Sri Lanka country report to CASTASIA II meeting, Manila.

7. Samarasekera H.T.P. (1956). Tropical Agriculturist - its agricultural content. Tropical Agriculturist 137: 5-10.

8. Ceylon Administrative Reports (1901). National Archives, Reid Avenue, Colombo.

9. Ceylon Administrative Reports (1902). National Archives, Reid Avenue, Colombo.

10. Ceylon Administrative Reports (1903). National Archives, Reid Avenue, Colombo.

11. Ceylon Administrative Reports (1905). National Archives, Reid Avenue, Colombo.

12. Joachim A.W.R. (1948). Presidential Address. Proceedings of the Fourth Annual Sessions of the Ceylon Association for the Advancement of Science, Part III, Colombo.

13. Ceylon Administrative Reports (1912). National Archives, Reid Avenue, Colombo.

14. De Silva M.A.T. (1973). Fertilizer experiments and coconut yields. Ceylon Coconut Planters' Review 7: 1-4.

15. Peries O.S. (1981). Rubber research in Sri Lanka. Tropical Agriculturist 137: 77-87.

16. Pain A. (1981). Agricultural research 1906-1981. Tropical Agriculturist 137: 3-12.

17. Gunasekera S. (1985). History of the Medical Research Institute. Journal of the Medical Research Institute of Sri Lanka 1: 1-8.

18. Ceylon Administrative Reports (1910). National Archives, Reid Avenue, Colombo.

19. Ceylon Administrative Reports (1918). National Archives, Reid Avenue, Colombo.

20. Ceylon Administrative Reports (1928). National Archives, Reid Avenue, Colombo.

21. Eden T., Gower J.C. \& Salgado M.L.M. (1963). A factorial experiment on coconuts. Empire Journal of Experimental Agriculture 37 (124): 283-195.

22. Annual Report (1967). Coconut Research Institute, Lunuwila.

23. Liyanage S.(1980). Emergence and development of scientific tradition in less developed countries (LDCs): the case of Sri Lanka in a comparative perspective. Proceedings of the Australian Association of Philosophy, History and Social Studies of Sciences 12(2): 289-311, Department of Philosophy, History and Social Studies, University of Wollongong, Australia.

24. Chemical Society of Ceylon 1941-1971 (1986). Mimeo.

25. Baker B. \& Herdt R. (1982). Setting priorities for rice research in Asia. In: Science, Politics and the Agricultural Revolution in Asia (Eds. R.S. Anderson, P. Brass \& B.M. Morrison), pp.427461. 
26. Wijesekera R.O.B.(1975). Scientific research in a small developing nation Sri Lanka. Scientific World 3(5): 6-9.

27. Jayasekera S. \& Kirtisinghe D.(2000). Agricultural research and development trends in Sri Lanka. In: Silver Jubilee Commemorative Volume (Eds. H.P.M. Gunasena., N. Sanderatne \& T. Jogaratnam), Post Graduate Institute of Agriculture, University of Peradeniya, Peradeniya, pp.105-115.

28. Senanayake Y.D.A.(2000). Science and technology in agriculture- Concept Paper. The First Biennial Conference on Science and Technology, National Science and Technology Commission, Colombo.

29. Natesan S.(1981). Development of agricultural education in Sri Lanka. Tropical Agriculturist 137: 55-61.

30. Jogaratnam T. (2000). The history of the Post Graduate Institute of Agriculture. In: Silver Jubilee Commemorative Volume (Eds. H.P.M. Gunasena., N.Sanderatne \& T. Jogaratnam), Post Graduate Institute of Agriculture, University of Peradeniya, Peradeniya, 13-25.

31. Senanayake Y.D.A. (1981). Role of the faculty of Agriculture in higher education in Sri Lanka. Tropical Agriculturist 137:99102.

32. Gunasena H.P.M.(2000 b). The Post Graduate Institute of Agriculture in the next millennium. In: Silver Jubilee Commemorative Volume (Eds. H.P.M.Gunasena., N. Sanderatne \& T. Jogaratnam ), Post Graduate Institute of Agriculture, University of Peradeniya, Peradeniya,pp. 59-71.

33. University Grants Commission (2005). Sri Lanka University Statistics 2004. Management of Information Systems Division, UGC, Ward Place, Colombo-07.

34. A rasasingham S.R. (1981). Agricultural extension in Sri Lanka. Tropical Agriculturist 137: 41-53.

35. APCTT (1989). A Framework for Technology Based Development.Vol. 6. Asian and Pacific Centre for Transfer of Technology, 49, Palace Road, Bangalore, India.

36. GOSL (2002). Regaining Sri Lanka:Vision and Strategy for Accelerated Development, Office of the Prime Minister, Government of Sri Lanka, Colombo.

37. CARP (2003). National Agricultural Research Policy, Sri Lanka Council for Agricultural Research Policy, Wijerama Mawatha, Colombo-07.

38. Rajapakse M. (2005). Mabinda Chinthana, Policy document prepared for the Presidential Election 2005. Print and Print Graphic (Pvt) Ltd. Colombo.
39. Pieris R. (1964). Universities, politics and public opinion in Ceylon. Minerva p.435.

40. Wijesekara R.O.B.(2001). Role of NASTEC in national development. In: Silver Jubilee Lecture Series - No. 4 Postgraduate Institute of Agriculture, University of Peradeniya, Peradeniya.

41. Liyanage S. (1987). Lessons from Sri Lanka's science and technology planning. Science and Public Policy 14(2): 59-70.

42. Annual Report (1983).Natural Resources, Energy and Science Authority, Maitland Place, Colombo-07.

43. GOSL (1986). National Science and Technology Policy for Sri Lanka. Department of Government Printing, Government of Sri Lanka, Colombo.

44. Vitarana T. (1996). Formulating an S\&zT policy for Sri Lanka in the context of globalization. Science, Technology and Society 1 (2): $249-266$

45. NARESA (1995). National SET Policy and a Plan of Action. Natural Resources Energy and Science Authority, 47/5, Maitland Place, Colombo-07.

46. MPI (1985a). Science and Technology policy for Sri Lanka, Ministry of Plan Implementation, Colombo.

47. MPI (1985b). Science and Technology policy for Sri Lanka, Ministry of Plan Implementation, Colombo.

48. CARP (1999). National Agricultural Research Plan. Sri Lanka Council for Agricultural Research Policy, Wijerama Mawatha, Colombo- 07.

49. Wickremasinghe S.I. (2004). National Agricultural Research Systems in India and Sri Lanka: study of organization, scientific community and their contribution to rice research. PhD Thesis, Centre for Studies in Science Policy, Jawaharlal Nehru University, New Delhi.

50. Swaminathan M.S. (2002). Shaping Sri Lanka's agricultural future: some suggestions for consideration, Report submitted to the Government of Sri Lanka, Colombo.

51. MOAL (2003). National Policy on Agriculture and Livestock 2003-2010, Ministry of Agriculture and Livestock, Govijana Mandiraya, Battaramulla.

52. Gert-Jan Stads, Gunasena H.P.M., Herath W. (2005). Agricultural Science and Technology Indicators- Sri Lanka, ASTI Country Brief No. 31, International Food Policy Research Institute, Washington D.C. 